\title{
Research on the Influence of Venture Capital on the Internal Control Quality Based on Data from China's GEM Listed Companies
}

\author{
Weihuan Jia* \\ Sichuan Agricultural University \\ College of Management \\ Chengdu, China
}

\begin{abstract}
Based on the importance of institutional investors to the development of enterprises, this paper studies the relationship between venture capital and internal control quality from the perspective of venture capital participation in corporate governance. This paper selects the relevant data disclosed by China's GEM listed companies in 2010-2016, and uses Stata12 to establish a regression model to empirically test the impact of venture capital on the internal control of the invested enterprise. The study found that venture capital can effectively improve the company's internal control quality when other conditions are constant, and the positive impact of non-government background risk investment on internal control quality is more significant than that of government-based venture capital. The above conclusions provide empirical evidence for the internal control governance of GEM listed companies, the introduction of venture capital and the encouragement of venture capital to play a supervisory role.
\end{abstract}

Keywords-Venture Capital; Internal Control Quality; GEM Listed Companies; Government Background

\section{INTRODUCTION}

The outbreak of the Enron incident in the United States in 2002 caused public opinion to pay attention to internal control. Later, the "Sarbanes-Oxley Act" promulgated by the United States promoted the development of internal control. Section 404 of the Act requires all listed companies to submit internal control reports in their annual reports. A detailed internal control report has led the world into a new era of comprehensive risk control. In 2008, China promulgated the "Basic Standards for Internal Control of Enterprises", and in 2010 issued relevant supporting guidelines, which marked the establishment of China's internal control norm system. In theory, internal control is an institutional arrangement implemented at different levels within the company to achieve established management objectives. A sound internal control system helps to improve the company's internal governance and accounting information quality.

The successful launch of the GEM in 2009 further improved China's capital market system, and the number of venture capital institutions and the total amount of investment also showed an excessive growth. As the most effective financing platform for SMEs, the GEM is the best way to solve the financing difficulties of SMEs. Venture capital is an equity investment that shares capital gains through holdings. Whether venture capital participates in corporate governance and effectively promotes the improvement of internal control quality is worth exploring.

Generally speaking, the introduction of venture capital is an effective way to improve the corporate governance structure, and it can strengthen the supervision of business management to improve the internal control quality of enterprises. However, there is currently little literature on the role of institutional investors in the quality of internal controls in academia. This paper takes the GEM listed companies as a sample, demonstrates the role mechanism of venture capital institutions in the internal control of GEM listed companies, strengthens the theoretical exploration of venture capital and internal control, and enriches the existing theoretical results. In order to better regulate the capital market, this paper explores and studies the effect of venture capital from different backgrounds on the internal control quality of GEM listed companies according to the actual situation of China's GEM, and provides experience for China's GEM companies to introduce venture capital. At the same time, it is of great reference value to provide corresponding countermeasures and suggestions for strengthening internal control and improving corporate governance.

\section{THEORETICAL ANALYSIS AND RESEARCH HYPOTHESIS}

Research on the involvement of venture institutions in corporate governance, Sahlman (1990) believed that venture capitalists had a strong incentive to participate in the management of the company to obtain a higher return on investment, and can better solve the problem of information asymmetry of entrepreneurs [1]. Meggison and Weiss (1991) found that venture capital played a role in information disclosure and certification in the business process of invested companies [2]. Manigart (2002) and Ronit (2008) believed that if too much participation in the daily management of the invested companies, the organization will easily generate more friction and lead to inefficiency, which is not good for the development of the invested companies [3][4]. According to the principal-agent theory, venture capital institutions are one of the shareholders of the company. On the one hand, compared with the external minority shareholders, the higher shareholding ratio enables them to play a more effective role in 
supervising and binding management; On the other hand, because venture capital institutions have a high proportion of shares, it can form a force to compete with major shareholders, thus alleviating the agency problem between major shareholders and minority shareholders. And the venture capital institution has strong financial strength, rich practical management experience and more professional judgment. By establishing a scientific internal control system and exerting the professional advantages of supervision and management, it can effectively improve the operating capacity and governance level of the invested company and prevent major strategic risks. On this basis, hypothesis 1 of this paper is proposed:

H1: Venture capital participation helps to improve the quality of the company's internal control, that is, the risk investment and the quality of internal control are significantly positively correlated.

Since most of the government-backed investment funds come from state-owned enterprises or governments at all levels, the fundamental purpose of the government to participate in venture capital is to support the development of small and medium-sized science and technology enterprises, which is to promote the overall scientific and technological progress of the country rather than obtain investment benefits. And the nongovernment-backed venture capital backing start-ups is designed to deliver fat returns. At home and abroad, it is found that the risk investment holdings of the government background have a special impact on enterprises: for example, Grilli and Murtinu (2014) and Alperovych (2015) thought that government VCs were not as good as private VCs [5][6]; Zhang Xueyong and Liao Li (2011) had shown that IPO underpricing rates were lower for companies supported by foreign-invested and mixed-type background ventures than those supported by government-backed venture capital investments [7]; Xu Hao (2015) used the data of GEM listed companies to conclude that government background risk investment has no impact on R\&D investment of enterprises, and private and foreign background venture capital investment had positively promoted $\mathrm{R} \& \mathrm{D}$ investment of enterprises [8]; $\mathrm{Hu}$ Zhangtao and Luo Huawei (2013) found that nongovernment-based venture capital institutions had a stronger inhibitory effect on financial distress than the governmentbased venture capital investment in small and medium-sized listed companies [9]. Therefore, in order to further explore the impact of different backgrounds of venture capital on the quality of internal control, this paper takes the government background as the separation variable of the sub-sample and proposes the second hypothesis of this paper:

H2: Compared with the government background, the nongovernment background of venture capital has a positive impact on the quality of internal control.

\section{RESEARCH DESIGN}

\section{A. Data source and sample selection}

The internal control quality data is derived from the DIB database. The risk investment data is the name of the shareholder in the prospectus of the listed company disclosed by cninfo.com.cn. If there is "risk investment", "starting investment", "risk capital" and "starting capital investment", it is recognized as venture capital; the distinction between government backgrounds is determined by examining whether the actual controllers of venture capital institutions have ministries, bureaus, local governments, and state-owned enterprises. Other data are obtained through the CSMAR database. Since the DIB internal control index of the GEM listed companies has only been disclosed since 2010, this paper selects the GEM listed company data for 2010-2016 to conduct research, and finally obtains 2058 full sample data. Among them, there are 165 sample data of government venture capital background and 1595 sample data of non-government venture capital background. All the data in this paper are processed by Stata12.

\section{B. Variable definition}

This paper selects the internal control(IC) quality as the explanatory variable. The "DIB Internal Control Index" is to design the basic index according to the five elements of the internal control framework, and to use the internal control defect as a correction variable to correct the basic index obtained in the previous section, and finally to obtain a comprehensive index for measuring the internal control level of the enterprise.

This paper selects the venture capital shareholding ratio (VCSR) as an explanatory variable. The distribution principle of one share and one power determines that the number of shares owned by shareholders will determine the overall ability of shareholders to control the company to a certain extent. The level of shares held by venture capital institutions will directly determine the application of the investment enterprise, and the degree of control in turn affects the quality of the enterprise's internal control.

In order to further explore the correlation between venture capital background and internal control quality, this paper uses sub-sample comparison research methods. The government background is used as a subsample to distinguish variables, and further explore the relationship between venture capital and internal control quality in the context of government and nongovernment. The variables are defined in TABLE I. 
TABLE I.

VARIABLE DESCRIPTION TABLE

\begin{tabular}{|c|c|c|}
\hline Variable name & $\begin{array}{l}\text { Variable } \\
\text { symbol }\end{array}$ & Variable definitions \\
\hline Internal control quality & IC & Add 1 to "DIB internal control index" and take natural logarithm \\
\hline $\begin{array}{c}\text { Venture capital } \\
\text { shareholding ratio }\end{array}$ & VCSR & $\begin{array}{c}\text { Is the sum of the shareholding ratio of venture capital institutions among the top ten shareholders of an } \\
\text { enterprise }\end{array}$ \\
\hline The company size & Size & The natural logarithm of the company's total assets \\
\hline Asset-liability ratio & Lev & The ratio of total liabilities to total assets \\
\hline Growth & Growth & Business income of the current year divided by business income of the previous year minus 1 \\
\hline Industry & Ind & $\begin{array}{l}\text { High-risk industries include information technology, healthcare, materials and energy, with a value of } 1 \text {. Other } \\
\text { industries are traditional industries, with a value of } 0\end{array}$ \\
\hline Year & Year & The study was 1 for years and 0 for years not \\
\hline
\end{tabular}

\section{Model construction}

In order to test the direct effect of venture capital on the quality of internal control of the invested enterprise, this paper constructs the following test model:

$$
\begin{gathered}
I C=\sigma_{0}+\sigma_{1} \text { VCSR }+\sigma_{2} \text { Size }+\sigma_{3} \text { Lev }+\sigma_{4} \text { Growth } \\
+\sigma_{5} \text { Ind }+\sigma_{6} \text { Year }+\varepsilon
\end{gathered}
$$

\section{EMPIRICAL RESULTS AND ANALYSIS}

\section{A. Descriptive statistical analysis}

Descriptive statistics of variables are shown in TABLE II. It can be seen from TABLE II that: (1) the maximum IC value is 6.6580 and the minimum value is 5.3910. In China's GEM enterprises, the difference in internal control quality is still significant; (2) the maximum shareholding ratio is $75.11 \%$ and the standard deviation is 14.10 , indicating that the shareholding ratio of venture capital institutions of sample companies varies greatly; (3) the size of companies in each sample company is also large, indicating that there is a certain gap between the development and maturity of each listed company on the GEM; (4) the average asset-liability ratio is 0.2674 , which means that most of the GEM companies may lack the ability to manage their debts, and they do not make full use of financial leverage to obtain higher returns. (5) from the perspective of enterprise growth, the minimum value is -0.7909 and the maximum value is 6.6845. The difference is also significant. Some companies have increased their growth rates, while others are struggling to stay steady.

TABLE II. DESCRIPTIVE STATISTICS OF VARIABLES

\begin{tabular}{|c|c|c|c|c|c|}
\hline & obs & min & max & average & Std \\
\hline IC & 2058 & 5.391 & 6.658 & 6.4887 & 0.1032 \\
\hline VCSR (\%) & 2058 & 0 & 75.11 & 10.5919 & 14.1003 \\
\hline Size & 2058 & 19.544 & 24.4475 & 21.1551 & 0.7272 \\
\hline Lev & 2058 & 0.0111 & 0.8864 & 0.2674 & 0.1616 \\
\hline Growth & 2058 & -0.7909 & 6.6845 & 0.2954 & 0.4849 \\
\hline
\end{tabular}

\section{B. Correlation analysis}

The Pearson correlation coefficient test results are shown in TABLE III below. The correlation coefficient between the risk investment variable and the IC value is 0.290 . The Pearson coefficient is tested at 0.05 level, indicating that the risk investment is significantly positively correlated with the internal control quality, and the hypothesis is initially verified; The scale of the enterprise is significantly positively correlated with the IC value. It has passed the test of the Pearson coefficient of 0.05 , indicating that the larger the enterprise, the more mature the development, the better the internal control system, and the higher the internal control quality of the enterprise; The asset-liability ratio is significantly negatively correlated with the IC value. It has passed the test of the Pearson coefficient of 0.05 , indicating that the company may be under excessive debts due to high debt-to-equity ratio, resulting in poor capital turnover and easy internal loopholes in internal control. Thereby reducing the internal control quality of the enterprise; the growth of the enterprise is significantly positively correlated with the IC value. It has passed the test of the Pearson coefficient of 0.01 , indicating that the better the growth of the enterprise, the more effective the internal control.

TABLE III. PEARSON CORRELATION TABLE

\begin{tabular}{|c|c|c|c|c|c|}
\hline & IC & VCS & Size & Lev & Growth \\
\hline IC & 1.000 & & & & \\
\hline VCSR & $0.290^{* *}$ & 1.000 & & & \\
\hline Size & $0.056^{* *}$ & $0.074^{* * *}$ & 1.000 & & \\
\hline Lev & $-0.055^{* *}$ & 0.011 & $0.411^{* * *}$ & 1.000 & \\
\hline Growth & $0.136^{* * *}$ & 0.029 & $0.263^{* * *}$ & $0.221^{* * *}$ & 1.0 \\
\hline \multicolumn{7}{|c|}{ Note: ***, **, and *indicate that the coefficient is significant at the level of $1 \%, 5 \%$, and $10 \%}$.
\end{tabular}

\section{Regression results and analysis}

After analyzing the regression results of the model, we get the following TABLE IV:

It can be seen from TABLE IV that in the whole sample, the VCSR coefficient of risk investment is 0.187 , which has passed the $1 \%$ significance test, indicating that the quality of internal control with venture capital participation is better, and the risk investment has a significant positive correlation with the quality of internal control. At the same time, it means that venture capital institutions have played a very good supervisory role in participating in the company's operation and management, which is consistent with the assumption 1 of this paper. In the sub-sample, although the regression coefficient of government background venture capital is positive, it is not as significant as that of non-government background venture capital. The former has a significant level of $10 \%$ and the latter has a significant level of $1 \%$, which indicates that both can improve the internal control quality of gem listed companies, but there is a strong positive correlation between nongovernmental background venture capital and the quality of internal control, so hypothesis 2 is proved.

From the size of the company, it is consistent with previous research results, that is, the quality of internal control increases 
with the size of the company. This shows that in the GEM listed companies, companies with large companies have the ability and resources to improve the internal control quality of enterprises, and large-scale enterprises need more effective internal control systems to maintain good production and operation.

In the regression results of the variable of asset-liability ratio, the coefficient of the whole sample and sub-sample is negative, and the significance test passes at the level of $1 \%$ and $10 \%$, indicating that the asset-liability ratio is too high and will exert a negative effect on the internal control of enterprises. Explain that controlling the asset-liability ratio within a reasonable range will help enterprises optimize their asset structure, help the use of financial leverage, improve the financial status of enterprises, and make internal control more effective, thereby improving the quality of internal control.

In the case of the variable of Growth, the coefficients in both the full sample and the subsample passed the significance test at the $1 \%$ and $5 \%$ levels, indicating that the higher value has a significant positive effect on the quality of internal control. This shows that the growth of corporate growth has brought higher quality internal control to the company, which is more significant in the non-government context than the government background.

TABLE IV. REGRESSION RESULTS OF THE IMPACT OF VENTURE CAPITAL ON INTERNAL CONTROL QUALITY

\begin{tabular}{|c|c|c|c|}
\hline & $\begin{array}{c}\text { All the } \\
\text { samples }\end{array}$ & $\begin{array}{c}\text { Government } \\
\text { background }\end{array}$ & $\begin{array}{c}\text { Non-government } \\
\text { background }\end{array}$ \\
\cline { 2 - 4 } & IC & IC & IC \\
\hline VCSR & $0.1867^{* * *}$ & $0.0789^{*}$ & $0.2008^{* * *}$ \\
\hline Size & $0.0203^{* * *}$ & $0.0104^{* *}$ & $0.0192^{* * *}$ \\
\hline Lev & $0.0604^{* * *}$ & $0.0965^{*}$ & $0.0655^{* * *}$ \\
\hline Growth & $0.0370^{* * *}$ & $0.0438^{* *}$ & $0.0348^{* * *}$ \\
\hline Ind & control & control & control \\
\hline Year & control & control & $6.524^{* * *}$ \\
\hline Constant & $6.913^{* * *}$ & $6.459^{* * *}$ & 1595 \\
\hline N & 2058 & 165 & $12.98^{* * *}$ \\
\hline F & $17.39^{* * *}$ & $3.17^{* * *}$ & 0.371 \\
\hline Adj-R & 0.367 & 0.323 & 0.0000 \\
\hline Prob & 0.0000 & 0.0000 & and $10 \%$. \\
\hline \multicolumn{2}{|c|}{ Note: ${ }^{* * *}, * *$, and $*$ indicate that the coefficient is significant at the level of $1 \%, 5 \%$, and }
\end{tabular}

\section{CONCLUSION}

The empirical results found in this paper:

Venture capital participation can significantly improve the internal control quality of GEM listed companies, indicating that venture capital institutions have the motivation to actively participate in corporate governance and supervise the invested enterprises, and improve enterprises by better regulating internal control of enterprises. High quality internal controls reduce investment risk and increase return on investment.

Venture capital with government background and venture capital and non-government background can effectively improve the internal control quality of GEM listed companies, but the positive impact of non-government background risk capital is more significant. It shows that venture capital with non-government background has stronger "certification supervision” ability, and the impact on improving the quality of internal control of the company is more significant than the government background.

This also proves that the venture capital institutions with private background, foreign investment background and mixed background are more likely to participate in the management of these enterprises in order to obtain investment income, and give full play to their own "value-added functions", which will bring obvious advantages and positive impacts to the internal control quality of enterprises; And the fundamental purpose of the government's participation in venture capital is to support these entrepreneurial enterprises, and their supervision and certification functions are weak.

\section{REFERENCES}

[1] W.A. Sahlman, The Structure and Governance of Venture Capital Organizations[J].Journal of Financial Economics,1990(02), pp. 473-521.

[2] W.L Meggision,. \& Weiss, K. Venture Capitalist Certification in Initial Public Offerings[J].Journal of Finance,1991(03), pp. 879-903.

[3] S. Manigart, The Survival of Venture Capital Backed Companies[J].Venture Capital,2002(02), pp. 103-124.

[4] Y. Ronit, Venture Capitals-entrepreneur Conflicts: An Exploratory Study of Determinants and Possible Resolutions [J].International Journal of Conflict Management, 2008(03), pp. 262-292.

[5] L. Grilli, \& S. Murtinu, Government, Venture Capital and the Growth of European High-tech Entrepreneurial Firms[J].Research Policy,2014 (09), pp. 1523-1543.

[6] Y. Alperovych, How does Governmental Versus Private Venture Capital Backing Affect a Firm's Efficiency? Evidence from Belgium[J].Journal of Business Venturing,2015 (04), pp. 508-525.

[7] Zhang Xueyong, Liao Li, Venture Capital Background and Corporate IPO: Market Performance and Internal Mechanism [J] Economic Research, 2011 (06), pp. 118-132. (In Chinese)

[8] Xu Hao. Venture Capital Background, Shareholding Ratio and R\&D Investment of Start-up Enterprises[J].Science Research,2015(10), pp. 1547-1554. (In Chinese)

[9] Hu Zhangwei, Luo Huawei. An Empirical Study on the Impact of Venture Capital on Financial Distress of Small and Medium-sized Listed Companies[J].Statistics \& Decision,2013(15), pp. 167-171. (In Chinese) 